\title{
Landscape and Settlement over 4 millennia on the south side of Lake Issyk kul, Kyrgyzstan: Preliminary Results of Survey Re- search in 2019-2021
}

\author{
Claudia Chang ${ }^{1}$, Sergei S.Ivanov ${ }^{2}$ and Perry A. Tourtellotte ${ }^{2, *}$ \\ Institute for the Study of the Ancient World; cchang@sbc.edu \\ 2 Kyrgyz National University; sergioive1982@gmail.com \\ * Correspondence: cchang@sbc.edu; Tel.: (+1 315-416-7268)
}

\begin{abstract}
This paper discusses the preliminary results of archaeological surveys conducted in the Juuku Region of north-central Kyrgyzstan on the south side of Lake Issyk kul. Our goal was to document ancient and contemporary agropastoral systems over a four millenia period. During the surveys about 350 loci were identified as settlements, burial mounds, graves, single artifact finds, and artifact scatters (ceramic). The areas of Juuku Valley survey included two discrete polygons: Polygon 1, Lower Juuku at 1750 to $1950 \mathrm{~m}$ asl in elevation and Polygon 2, Chak Juuku or Upper Eastern Branch Juuku Valley at 2060 to $2100 \mathrm{~m}$ asl in elevation. Three radiometric dates and preliminary archaeobotanical studies were conducted at three exposed profile cuts. The methods included here are: (1) pedestrian surveys; (2) use of digital maps (Google Earth, Encarta); (3) placing archaeological loci within known chronological time periods; (4) AMS dating of charcoal samples collected from profile deposits; and (5) preliminary identification of plant remains found from archaeobotanical samples. The results of our research represent the first step toward inventorying and interpreting archaeological data in the Juuku Valley derived from field studies.
\end{abstract}

Keywords: Archaeological survey; Inner Tian Shan Mountain region; Iron Age; Medieval period; agropastoralism

\section{Introduction}

We investigate the impact of ancient farming and herding systems upon the natural landscape of a river valley and alluvial fan of the Inner Tian Shan Mountain region over a four millennium time period. The Inner Tian Shan region is an important part of the historically known trade and migration routes described as the proto-Silk routes and by others as the Inner Asian Mountain Corridor [1] linking the desert-oases of Central Asia, the Eurasian steppe, and the territories of the Chinese Dynasties from the Bronze Age (ca 2500 BCE to 900 BCE) through contemporary times. This article reports on the preliminary results of pedestrian surveys conducted in 2019 and 2021 in the Juuku Valley on the south side of Lake Issyk kul. This landscape ranges from high alpine meadows surrounded by conifer forests to semi-arid grass-covered steppe lands. Our working hypothesis is that ancient farming and herding practices along with human settlement over a landscape were shaped by the local climate and environment, while in turn such human activities altered those natural landscapes. To test this hypothesis, we chose two sample polygons in the Juuku Valley for field survey, one in the upper valley and the other in the lower reaches. Our objective is to examine the long-term effects of land clearing for farming and herding as well as the alteration of land surfaces through the construction of architectural features. The results of our field seasons include an inventory of approximately 350 activity loci. We collected radiocarbon samples and sediment samples from three site profiles. The soil samples have been analyzed by archaeobotanists who identified the remains of ancient seeds. These preliminary results shall contribute to the larger discussion of Late Holocene human impact upon the mountainous regions of Central Asia. As such, this is 
the first step toward creating site inventories that can be used as future planning tools for land development, cultural heritage, and the preservation of natural landscapes in the Issyk kul basin.

New forms of evidence for explaining the trade, communication, and migration networks of the intermontane regions of Central Asia and their importance to the Eurasian steppe have included detailed archaeobotanical research tracing the pathways of domesticated plants [2-6]. Ancient DNA studies have traced human population movements [79], while isotope analyses of ancient human and animal bone materials have documented mobility and dietary practices $[10,11]$. These laboratory studies on ancient plant, animal, and human remains augment a rich inventory of material culture from archaeological settlements. Our research turns to a more mundane, but important strategy for examining ancient mobility patterns in a single valley area. Dince the 1990s archaeologists have used basic survey methods for finding and inventorying archaeological sites in the Tian Shan mountains and surrounding region for the Iron and Bronze Age materials in the neighboring Republic of Kazakhstan [12-17]. In the Western Tian Shan, ethnoarchaeological observations on the seasonal movements of pastoral tranhumants, in particular, have noted the use of winter and spring/autumn camps, thus suggesting that the Bronze Age agropastoral site of Adunoqiaolu was occupied also during winter months [18, 19]. Survey research at Juuku Valley serves as an excellent contrast to previous archaeological survey research on the alluvial fans of the northern Tian Shan range [12, 14, 15].

In 2018 and 2019 archaeological surveys in the Kochkor Valley of the Inner Tian Shan. Lynne Rouse and her colleagues [20,21] have undertaken UAV surveys and GIS mapping in the Kochkor Valley, also situated on the south side of Lake Issyk kul. The objectives of their surveys have been to record upland archaeological features dating from the Bronze Age through Medieval periods in conjunction with archaeological excavations conducted at the upland site of Chap at $2000 \mathrm{~m}$ asl. that has deposits dating from 1065 $\mathrm{BCE}$ to 825 BCE. Rouse and her colleagues intend to document the Inner Asian Mountain corridors along this important passageway of the Inner Tian Shan range [20]. During the Late Bronze occupational phase, archaobotanists have discovered ancient seeds of Hordeum vulgare (hulled and unhulled barley), Triticum (free-threshing and possible glume wheats), Panicum miliaceum (broomcorn millet) Setaria italica (foxtail millet) and $\mathrm{Pi}$ sum sativum (pea) [22-24]. Indeed, current research on plant and animal remains and material culture throughout Central Eurasia have demonstrated the importance of agropastoralism from the Bronze through Medieval periods [25].

\subsection{Study Area}

The environmental setting and physical landscape features of the Juuku Valley (see Locator Map, Figure 1) are also important for documenting both anthropogenic and nature-induced changes in the Juuku Valley during the late Holocene. The Juuku Valley is a small intermontane valley formed by the mountain streams flowing southward to Lake Issky kul. The lake itself is fed by 102 streams and rivers, and fluctuates $20 \mathrm{~cm}$ in water level due to glacial melt [26]. The main glacier peak of this valley is It Tash (elevation $4808 \mathrm{~m}$ ) and the entire valley extends $50 \mathrm{~km}$ north towards the southern littoral of Lake Issyk kul. The geology of Juuku Valley is similar to that of Dzhety-Ogyuz valley to the east. The Paleozoic granites and metamorphic rocks are the foundation for the Dzhety-Ogyuz valley and neighboring valleys. Overlaying these granites are Jurassic quartzites. The Eocene and Pliocene deposits consist of a series of red sandstone formations. The surface alluval deposits of indeterminate age include gravels, pebbles, sand, and soils. The valleys and gorges on the south side of the Issyk kul basin have been subject to frequent earthquake disturbances, many impacting Medieval settlements [27, 28].

The vertical zonation below the glaciers consists of rocky terrain with some traces of desert-like vegetation. From 3400 to $3000 \mathrm{~m}$ there are grassy meadows and a sub-alpine climate and at elevations of $3000 \mathrm{~m}$ to $2000 \mathrm{~m}$, Tian Shan spruce trees surround meadows 
of perennial grasses and shrubs. This is the upland zone (2000 to $3000 \mathrm{~m}$ ) currently used by Kyrgyz herders for grazing sheep, goats, cattle, and horses and for cultivating small fields of barley and fodder crops. In our study area this upland zone is demarcated as the Upper Juuku Valley. From here, the gorge opens into the Lower Juuku, an alluvial valley consisting of terraces and benches above the streams and rivers (an area of about $10.5 \mathrm{sq} \mathrm{km}$.). Below this alluvial valley is a large alluvial fan (44 sq $\mathrm{km})$ where the Juuku River empties into Lake Issyk kul. The Lower Juuku area today has large, irrigated fields of wheat, barley, and oats, alfalfa and hay; flocks and herds of animals graze along the edges of the fields and in stubble areas. Along the far reaches of the alluvial fan near the shoreline of Lake Issyk kul (ca. $1600 \mathrm{~m}$, there are marshlands and rich pasture areas.

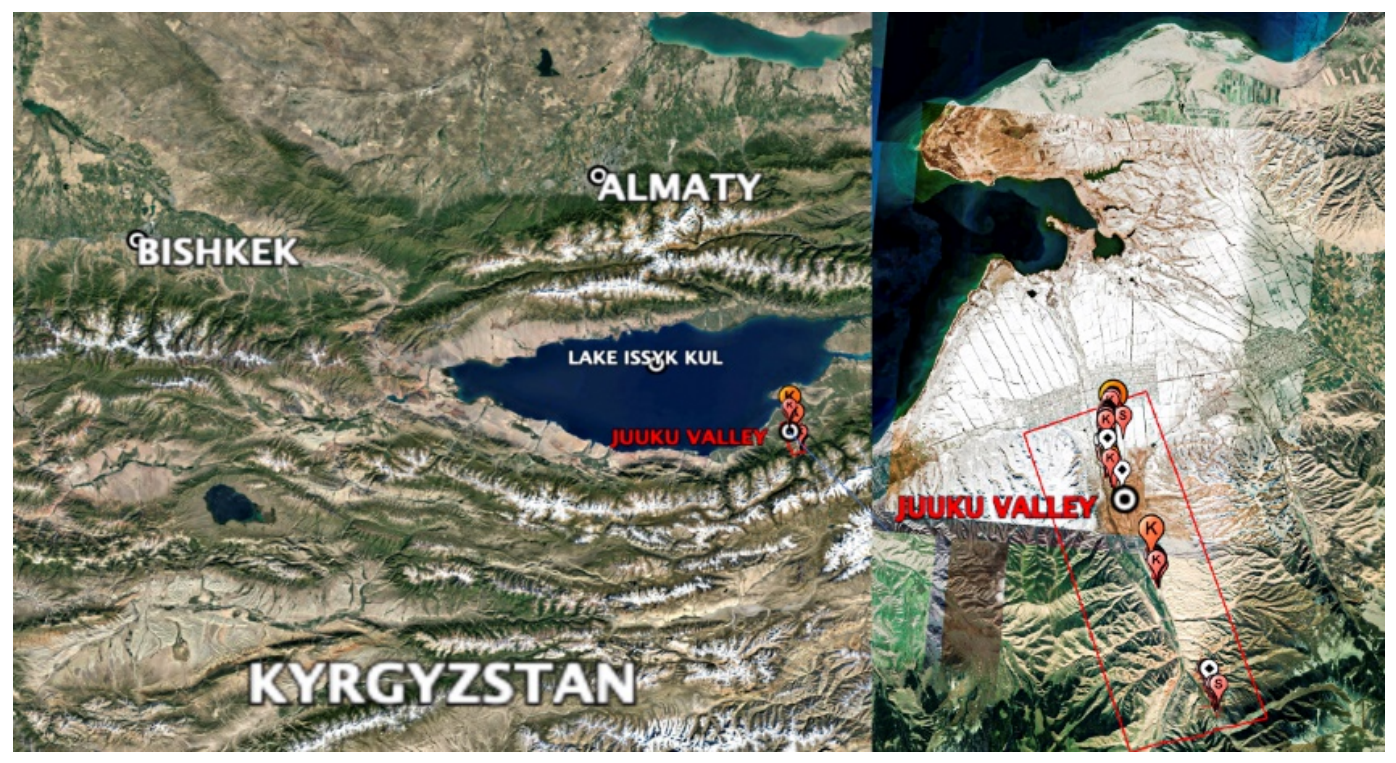

Figure 1. Locator Map of Juuku Valley.

\section{Materials and Methods}

Two sample polygons in the Juuku Valley were chosen for intensive survey because they appeared to have a high density of kurgans and architectural features. Polygon 1 in the Lower Juuku Valley, an area of $6.4 \mathrm{sq} \mathrm{km}$, is situated in the productive zone of wheat, barley, oats, fodder plants, and winter grazing in 1750 to $1900 \mathrm{~m}$ asl. The $6.4 \mathrm{sq}$ $\mathrm{km}$ area is approximately half of the total alluvial valley of the Lower Juuku Valley. Below this alluvial valley is a large fan that reaches the southern shoreline. Polygon 2 in the Upper Juuku Valley, an area of $0.5 \mathrm{sq} \mathrm{km}$, consists of a series of terraces and narrow floodplain with steep colluvial deposits along the eastern branch of the Juuku River. Polygon 2 is situated in the zone of summer pasture area, tourist camping, fishing spots, and forest service reserves at elevations of $2000 \mathrm{~m}$ to $2100 \mathrm{~m}$ asl. The pedestrian surveys conducted by a team of three field archaeologists were aided by inspection of imagery from Google Earth, Soviet maps, and other digital maps (Encarta). The loci were recorded using Garmin GPS units. Each locus was recorded by coordinates, described, and photographed in the field. From detailed notes, Excel spreadsheets were created for all site and artifact loci. During 15 field days in 2019 and 30 field days in 2021 we amassed an inventory of over 1000 loci from the Kizil Suu, Saruu, and Juuku Valleys. Field surveys were also carried out in upland areas of Sutti Bulak, Chichi Khan, Kadzhi Sai, and Chong Kizil Suu.

In addition to surface survey, we also recorded archaeological features such as pits, house structures, storage pits and fire pits found in exposed stratigraphic profiles. Many of the exposed stratigraphic profiles were erosional or river cuts or the result of road construction and farming activities. Three stratigraphic profiles found at settlement sites were selected for more detailed analyses. Radiocarbon samples and soil samples for archaeobotanical analyses were taken from these hree exposed profiles, one in the Lower 
Juuku polygon and two in the Upper Juuku polygon. In Polygon 1 (Lower Juuku), at Loci 387, large burnt wood samples for radiometric dating and an archaeological soil sample of 17 liters was collected from a house pit. In Polygon 2, two stratigraphic profiles from two different erosional cuts were identified as archaeological house pit fills containing mudbrick remains, plastered floors and midden deposits. At Settlement 1 profile, 14.5 liters of soil was collected for archaeobotanical analyses and a small charcoal sample was removed for radiometric dating. Then at Settlement 2 profile, 11.5 liters of soil was collected for archaeobotanical analyses and a charcoal sample was removed for radiometric dating. The soil samples were processed in the Republic of Kyrgyzstan using a SMAP flotation machine with mechanized agitation to wash sediments. The agitation process washes the archaeological sediments so that organic materials are caught in the overflow spout in geological sieves of $0.344 \mathrm{~mm}$ mesh. These organic materials are referred to as the light fraction, and when sorted, often contain carbonized seeds, pits, leaves and other remains. The organic materials that sink to the bottom of the agitation tank are referred to as the heavy fraction and these remains are collected in $1.4 \mathrm{~mm}$ mesh screen. Both heavy and light fractions were sorted using atlases for seed identification [29.30] by two archaeobotanists at the Max Planck Institute for Human History, Archaeobotany Laboratory [31]. The wood samples collected for radiometric dating were analyzed using Accelerated Mass Spectrometry at the Beta Analytic Laboratory in Coral Gables, Florida. Preliinary archaeobotanical and radiometric analyses of these three stratigraphic columns represent very preliminary data that shall be used for refining a regional chronology for settlements and for designing a more comprehensive research study of human land-use along a vertical gradient.

\section{Results}

During the 2019 and 2021 surveys we registered about 350 loci (single artifact finds, sherd scatters, graves, burial mounds (kurgans), house foundations, house depressions in the Lower Juuku and Upper Juuku. These loci were also placed in chronological sequences based on local typologies for burial monuments, settlements, and artifacts (ceramics). Our initial observations suggest that the large Medieval settlements (fortresses, citadels, caravanserais, proto-urban towns) found in Juuku and the neighboring valleys of Sutti Bulak, Chichi Khan cover over and obscure earlier Bronze and Iron Age settlements. When both Medieval and Iron Age ceramic sherds are found on the same land surfaces and loci this indicates that $t$ later Medieval deposits cover over and obscure earlier Iron Age settlement features. The prominent appearance of above-ground mortuary features such as Iron Age burial mounds (kurgans), often 5 to $50 \mathrm{~m}$ in diameter and 0.1 to $3 \mathrm{~m}$ or more in height, situated near Medieval walls, farmsteads, and dwellings demarcate clear spatial boundaries between Medieval settlements and Iron Age cemeteries and mortuary complexes. Logically this also means that the places where Iron Age burial mounds exist today are landscapes that were not used by later populations for house or settlement construction. These landscape palimpsests are essential to developing a deeper and more nuanced approach to site and non-site archaeology in regional contexts $[32,33]$.

\subsection{Chronology:}

During the survey we established a local historical chronology based on archaeological and historical sources from the Tian Shan and surrounding regions. These phase designations are based on archaeological research conducted in Kyrgyzstan over the past one-hundred years on settlements, burial mounds, graves, and artifact collections throughout north-central Kyrgyzstan and the Semirech'ye region of southeastern Kazakhstan [34-36]. During the Soviet period Vinnik identified about 17 Medieval period settlements along the SW coast of Lake Issyk kul [37]. Local expertise allowed us to place our survey findings into these chronological and phase designations [34, 38]. 
Table 1. Table 1. Time Periods, Phase Designations and Dates used for the Juuku Valley Survey.

\begin{tabular}{|c|c|c|}
\hline Time Period & Phase Designation & Dates \\
\hline \multirow[t]{2}{*}{ Late Bronze Age } & & 2000 BCE - 900 BCE \\
\hline & Final Bronze & $1100 \mathrm{BCE}-800 \mathrm{BCE}$ \\
\hline \multirow{4}{*}{ Iron Age } & & $800 \mathrm{BCE}-550 \mathrm{CE}$ \\
\hline & Saka & 800 BCE - 260 BCE \\
\hline & Wusun & $140 \mathrm{BCE}-437 \mathrm{CE}$ \\
\hline & Kenkol (only in TianShan) & $200 \mathrm{CE}-550 \mathrm{CE}$ \\
\hline \multirow{3}{*}{ Medieval Period } & & $500 \mathrm{CE}-1500 \mathrm{CE}$ \\
\hline & Turkic Period & $552 \mathrm{CE}-900 \mathrm{CE}$ \\
\hline & Qarakhanid & $942 \mathrm{CE}-1228 \mathrm{CE}$ \\
\hline Early Kirghiz & & $1500 \mathrm{CE}-1700 \mathrm{CE}$ \\
\hline Kirghiz Ethnographic Period & & 1700 CE - Present \\
\hline Soviet Period & & $1917-1991$ \\
\hline Post-Soviet, Kyrgyz Nation & & $1991 \quad-$ \\
\hline
\end{tabular}

3.2. In this section we discuss the survey results and include some preliminary descriptions and results of three stratigraphic profiles. Each survey polygon is a self-contained unit of analysis so as not to confuse the reader.

3.3. Polygon 1 is a survey area (ca. $6.4 \mathrm{sq} \mathrm{km}$ ) located on the Lower Juuku alluvial valley where the terraces rise about $30 \mathrm{~m}$ above the entrenched stream bed and is situated about $6 \mathrm{~km}$ south from the shores of Lake Issyk kul (Figure 2). In this polygon the terraces often rise up to $30 \mathrm{~m}$ above the entrenched stream and riverbed. Today the upper alluvial valley is farmed by tractor and heavy equipment where large, irrigated fields are cultivated in crops of wheat, barley, oats, and fodder crops. The 323 loci documented in the 2019 and 2021 surveys are found between $1750 \mathrm{~m}$ asl and $1950 \mathrm{~m}$ asl. There is a density of 50 loci per sq $\mathrm{km}$.

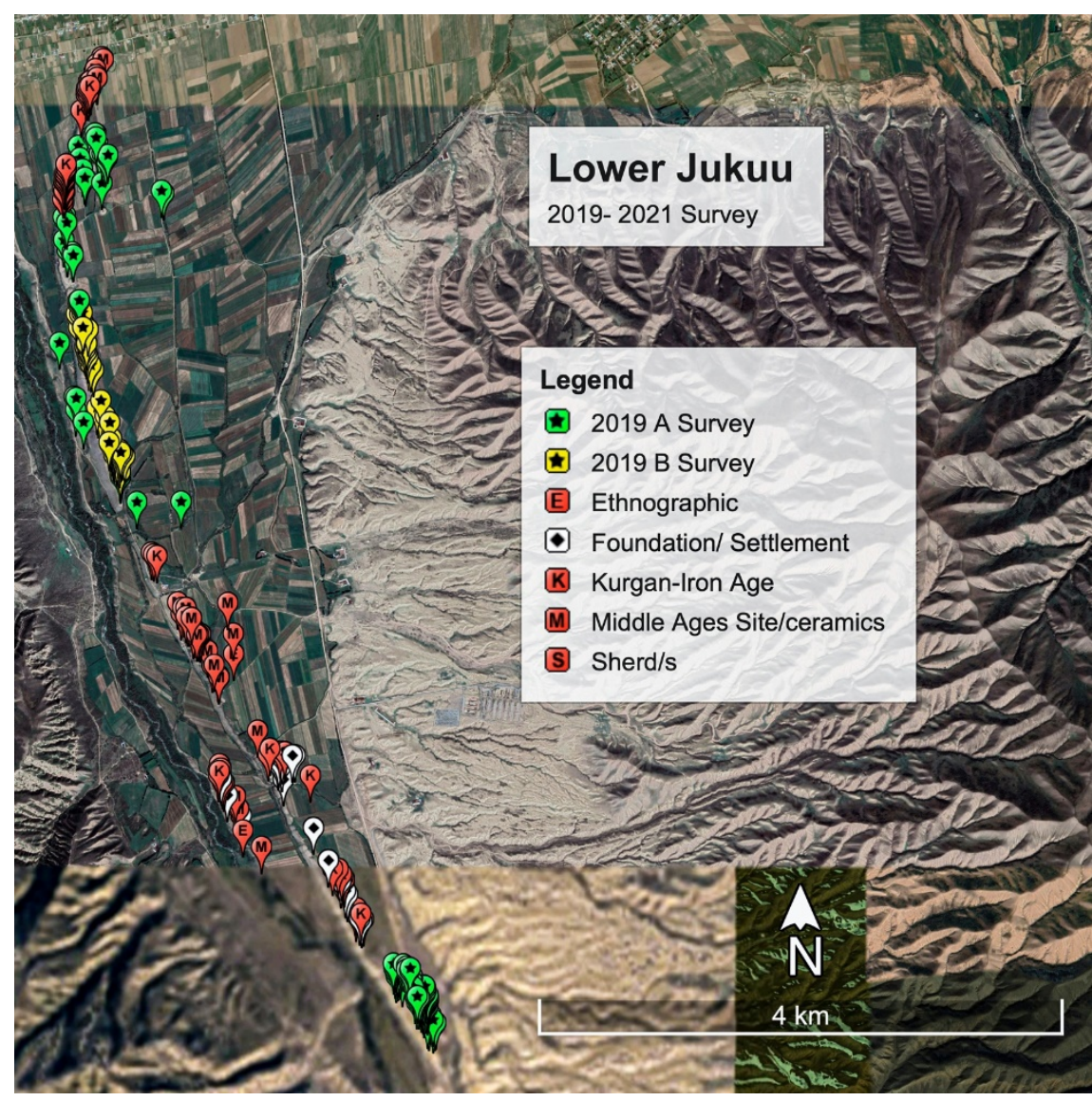

Figure 2. This Lower Juuku Google Earth Image. Survey Data. 


\subsubsection{Site types found in Lower Juuku}

The majority of loci found from survey were mortuary remains: 192 mortuary remains (burial mounds, graves and 1 mausoleum) were found, a total of 31 settlement and architectural features (17 settlement sites), and 21 artifact finds (Figure 3).

3.3.2.

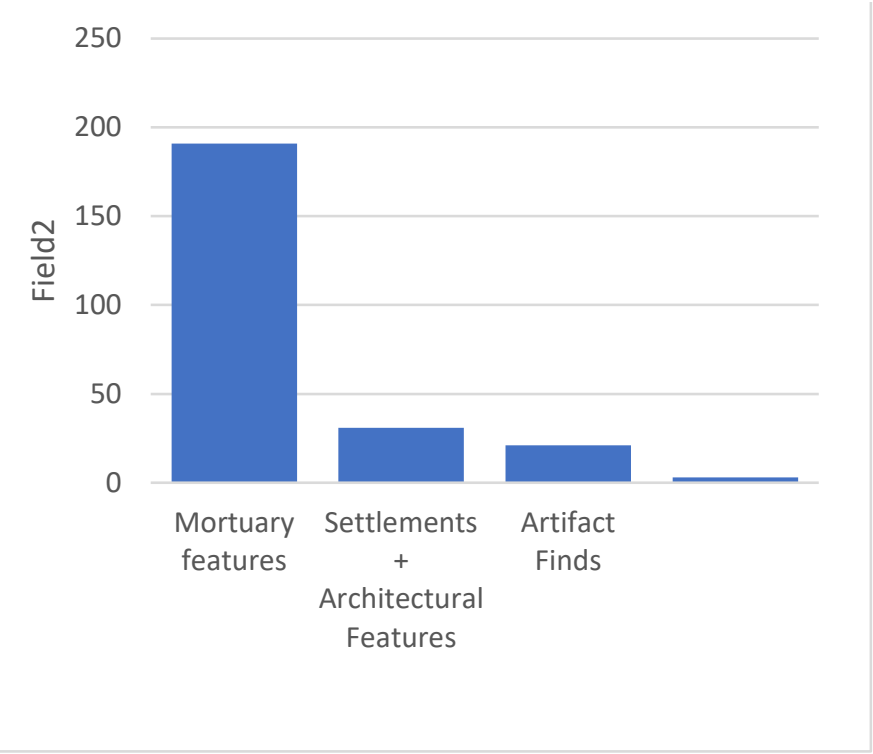

Figure 3. Histogram of Site Types in Lower Juuku: Mortuary Features, Settlements and Architectural Features and Artifact Finds.

\subsubsection{Settlements in Polygon 1}

A total of 17 settlements have been identified in Lower Juuku. The settlements assigned to specific time periods according to ceramic and artifact finds in addition to architectural features such as the citadel (shakristan), the surrounding residential areas (rabat), stone foundations and room or house depressions.

\subsubsection{Loci 387: Historic or Ethnographic Kirghiz House}

One site (Loci. 387) is a large settlement located on the eastern bank above the lower Juuku stream at an elevation of $1892 \mathrm{~m}$ asl. The profile section, located along the south bend of a road cut, is $4.5 \mathrm{~m}$ in length and $1.4 \mathrm{~m}$ in depth from the present ground surface (Figure 4). In the profile is the housefill of a structure built of mudbrick that was destroyed by a bulldozer cut when building the dirt road. The humic layer covers a thick layer of mudbrick (about $20 \mathrm{~cm}$ thick). Underneath the humic and upper mudbrick layer is a thick midden deposit about 40 to $60 \mathrm{~cm}$ thick. This midden layer consists of a thick lens of cultural material including animal bones (cattle), and chunks of charcoal some as large as $1 \mathrm{~cm}$ in diameter. No artifacts were found in the profile, although coarseware ceramic sherds were found on the ground surface near the road cut. The flotation samples were taken from this thick cultural level about $60 \mathrm{~cm}$ from the present ground surface along with over 10 grams of burnt wood (charcoal) for radiometric dating. At $60 \mathrm{~cm}$ to 1 $\mathrm{m}$ below the present ground surface was a thick layer of mud brick foundations, yellow buff in color. This mudbrick layer may have been the original floor level because below the mudbrick were large river cobbles probably used as foundation stones. Upon initial inspection we identified the site as a Medieval settlement, however the radiometric dating places it within the ethnographic Kirghiz period. A radiometric sample taken from the cultural level places this settlement within the ethnographic Kirghiz time period (floruit $1682-1932$ cal CE). In the opinion of the researchers, it is doubtful that the charcoal 
samples were contaminated by either natural or cultural forces due to the intact stratigraphy found in this road cut.

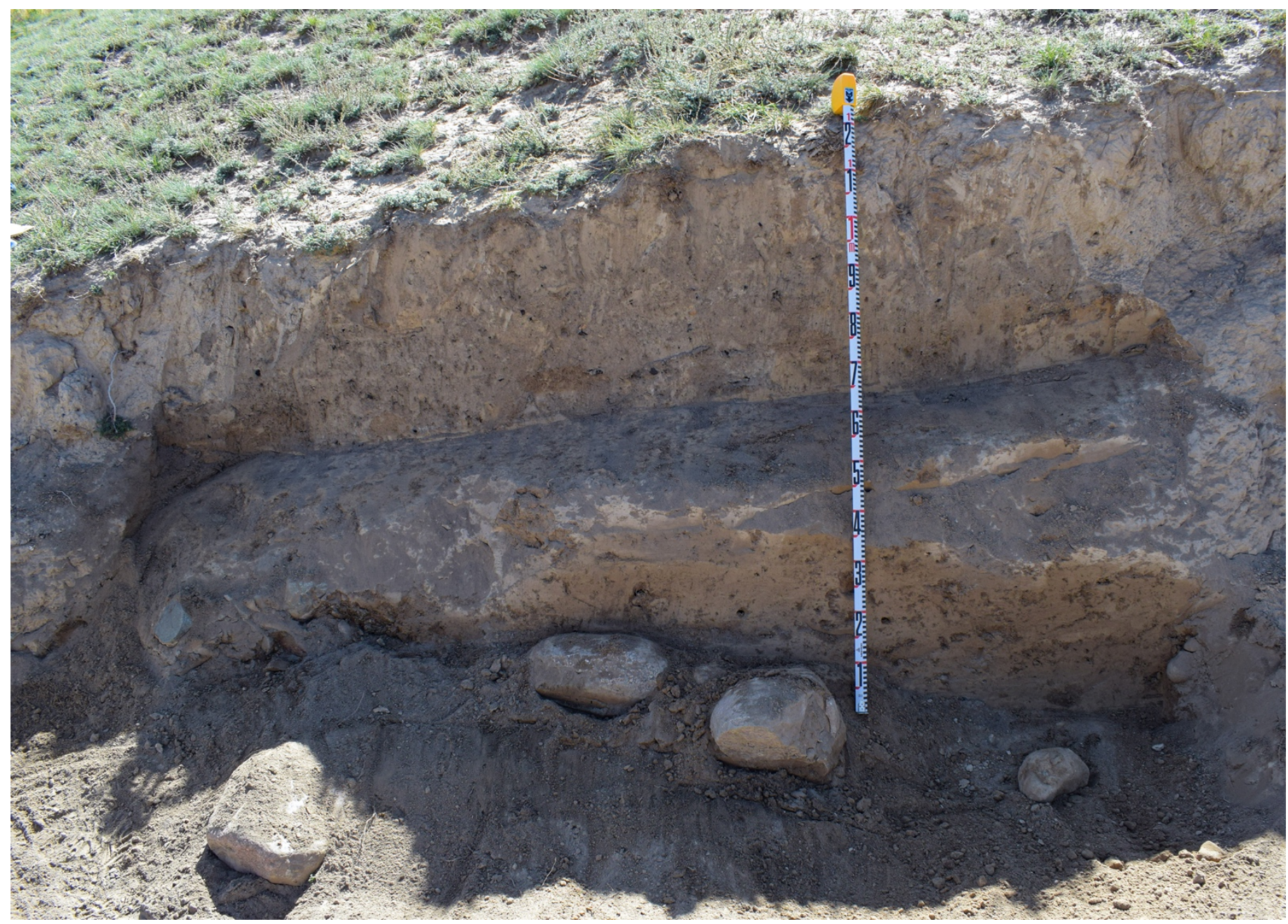

Figure 4. Photograph showing the Profile of the Kirghiz Ethnographic Period Settlement .

Table 3. Results from Radiocarbon Sample of Loci. 387.

\begin{tabular}{ccc}
\hline Beta $\mathbf{- 6 0 3 7 8 1}$ & Calibrated Dates AD & $\begin{array}{c}\text { Conventional radiocarbon age BP (Before } \\
\text { Present) }\end{array}$ \\
\hline $\mathbf{6 8 . 6 \%}$ & $1800-1932 \mathrm{cal} \mathrm{AD}$ & $150-12 \mathrm{cal} \mathrm{BP}$ \\
\hline $\mathbf{2 5 . 7 \%}$ & $1682-1738 \mathrm{cal} \mathrm{AD}$ & $268-212 \mathrm{cal} \mathrm{BP}$ \\
\hline $\mathbf{1 . 2} \%$ & $1754-1762 \mathrm{cal} \mathrm{AD}$ & $196-186 \mathrm{cal} \mathrm{BP}$ \\
\hline
\end{tabular}

These results were obtained using AMS radiocarbon methods and have been calibrated using INTCAL20 by Beta Analytic, Inc [39]. These results are reported in this manner based upon the report provided by Beta Analytic, Inc. for precise reading of their AMS dating protocol.

\subsubsection{Preliminary Archaeobotanical results from Loci 387}

A caveat is in order here. Most archaeobotanical studies conducted at sites like the Chap site, a Late Bronze Age site and Paykend, a Qarakhanid Medieval site depend on the collection of large samples of archaeological sediments, sometimes entire house fills or pit fills $[22,40]$. Our soil samples are very small and can only be considered as preliminary in nature. Thus. the results from the flotation of these samples must be interpreted as preliminary results and shall be reported upon in greater depth in another publication. From the 17liter sample, the archaeobotany team discovered a total of 41 seeds, the 
majority wild plants. The field crops included barley, wheat, and peas, along with the major component of carbonized chenopods and weed seeds of wild Fabaceae and grasses (Poacae) [31].

3.4 Polygon 2 or Upper Juuku (Chak Juuku) is $20 \mathrm{~km}$ from the edge of the Lake and is a narrow valley that consists of dissected terraces on either side of the eastern branch of the Juuku Gorge, a section where red sandstone formations form the steep gorge (Figure 5). This survey area consists of the two banks of the Eastern Juuku stream and is about $0.5 \mathrm{sq} \mathrm{km}$ in area. Approximately 37 loci were identified, or a density of 74 loci to $1 \mathrm{sq}$ $\mathrm{km}$. The loci range from $2060 \mathrm{~m}$ asl to $2100 \mathrm{~m}$ asl. The natural vegetation includes semiarid shrubs and grasslands with pockets of spruce in the higher elevations and willows and aspens and other riparian species along the stream banks.

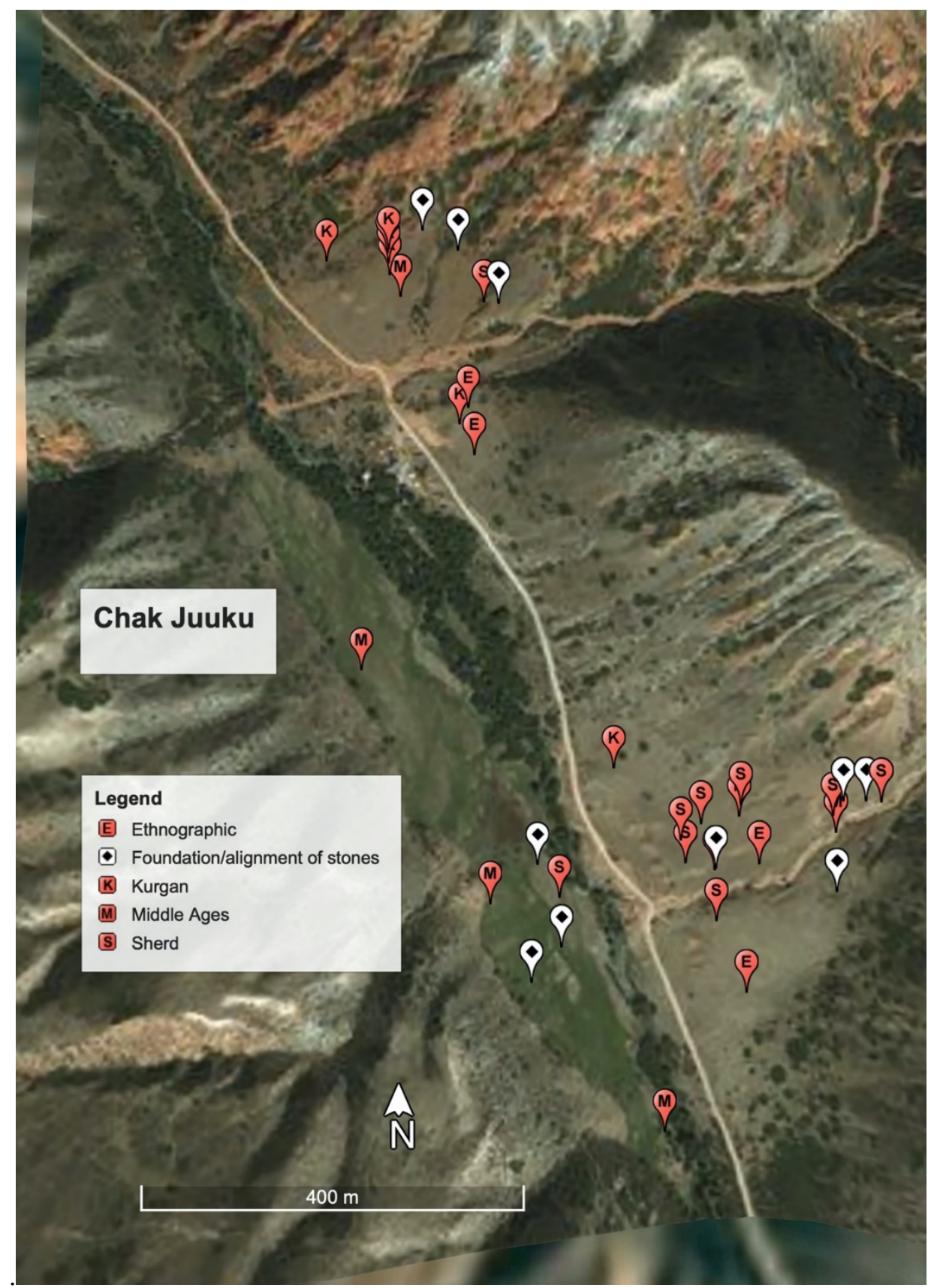

Figure 5. Upper Juuku (Chak Juuku), Google Image, Survey. 
3.4.1. In Table 4 we describe the settlements, burial mounds, and graves, and artifact finds in the Chak Juuku area. In addition there are 2 other settlements of unknown age (Loci 184 and Loci 185) found in the vicinity of the Settlement 1, the Wusun period site. It is possible that these stone foundations could be associated with Settlement 1, although no temporal indications such as ceramic sherds were found at these settlements.

Table 4. Sites and Finds from Upper Juuku by time period.

\begin{tabular}{cc}
\hline Chronological Period & Settlements \\
\hline $\begin{array}{c}\text { Ethnographic Kirghiz Period } \\
\text { (1700 CE to Present) }\end{array}$ & $\begin{array}{c}\text { Stone corral with possible room } \\
\text { blocks }\end{array}$ \\
& \\
& \\
& \\
& \\
Settlement 2 (17,5 m X 12 m), 3-5 \\
rooms, double stone wall \\
construction, Qarakhanid Period, \\
Redware sherd, Grinding Stone \\
fragment (KS 165/493) \\
Settlement 4: Large mudbrick and \\
stone complex on w. bank of Chak \\
Juuku stream, 51 m X 20 m \\
(KS 498) \\
Medieval Period (500 to 1500 CE) \\
Settlement 5 or Mill: Double stone wall \\
construction, on west bank of Chak \\
Juuku stream, 8 m X 6 m (KS 500) \\
Settlement 6: Mudbrick room block (2 \\
rooms), $5 \mathrm{~m}$ X 10 m, on west bank of \\
Chak Juuku stream, (KS 501)
\end{tabular}

3 Qarakhanid glazed ceramics , 5+ redware sherds found at modern corral (KS 191)

Mortuary Remains
Group 1 (10+ stone graves KS 144)
Group 2 (6+ stone graves KS 181)
Group 3 (2 stone graves KS 174)
Single Stone Grave (KS 160)
$\quad$ Single Stone Grave

(KS 502)
Iron Age (Saka and Wusun period, ca. $800 \mathrm{BCE}$ to $437 \mathrm{CE}$ )
Settlement 1: Double stone alignments, consisting of four rooms with deep depressions, $15 \mathrm{~m} \times 10 \mathrm{~m}$, , 1 redware rim, (KS 182-83
Saka kurgan group 1: 5 stone kurgans, (KS 21.186-88 and possibly KS 190)

3 separate Saka kurgan, (KS 177, KS 180, KS 192)
1 redware sherd with yellow slip, (KS 21.192)

3.4.2. Settlement 1 situated at $2057 \mathrm{~m}$ in elevation on an upper terrace above a ravine. It is a Wusun Period site dating from 22 -206 cal AD (see Table 4). The surface features

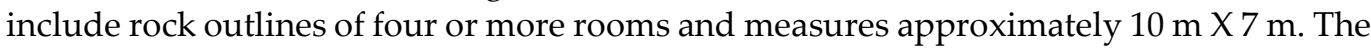
erosional cut is about $2.5 \mathrm{~m}$ in depth from the surface and runs in an east-west direction from the reaches of a small sandstone canyon that disects this terrace. The stratigraphic 
profile is located on a south-facing erosional cut found on a steep terrace bank at $2044 \mathrm{~m}$ asl. The exposed profile is $3 \mathrm{~m}$ in length and has a depth from the present ground surface $2 \mathrm{~m}$ in depth (Figure 5). There are roughly about six different archaeological layers within the house pit fill. Each layer is arouns 20 to $30 \mathrm{~cm}$ thick of midden deposit consisting of chestnut and red-clay soils intermixed with charcoal and disintegrating mudbrick. There were many animal bones fragments and one cattle vertebrate found at 80 $\mathrm{cm}$ below the present ground surface. A redware Iron Age ceramic with white slip discovered at $90 \mathrm{~cm}$ below the surface. There were at least three discernible layers of thin plaster floors. At about $1.5 \mathrm{~m}$ below present ground surface there were small angular stones and small pebble and sand deposits that appear to be subsoil (non-cultural soil). From an exposed profile of charcoal room fill, three archaeobotanical soil samples (14.5 l) were taken in layers 4 and 5, near where the Iron Age ceramic sherd was found. The small charcoal sample was also taken in the same vicinity.

3.4.3 Preliminary archaeobotanical remains found at Settlement 1 . There were a small number of carbonized seeds identified from four domesticated crops including barley, wheat, broomcorn millet and foxtail millet. More than half the assemblage included wild plants such as chenopods, wild legumes and cleavers [31].

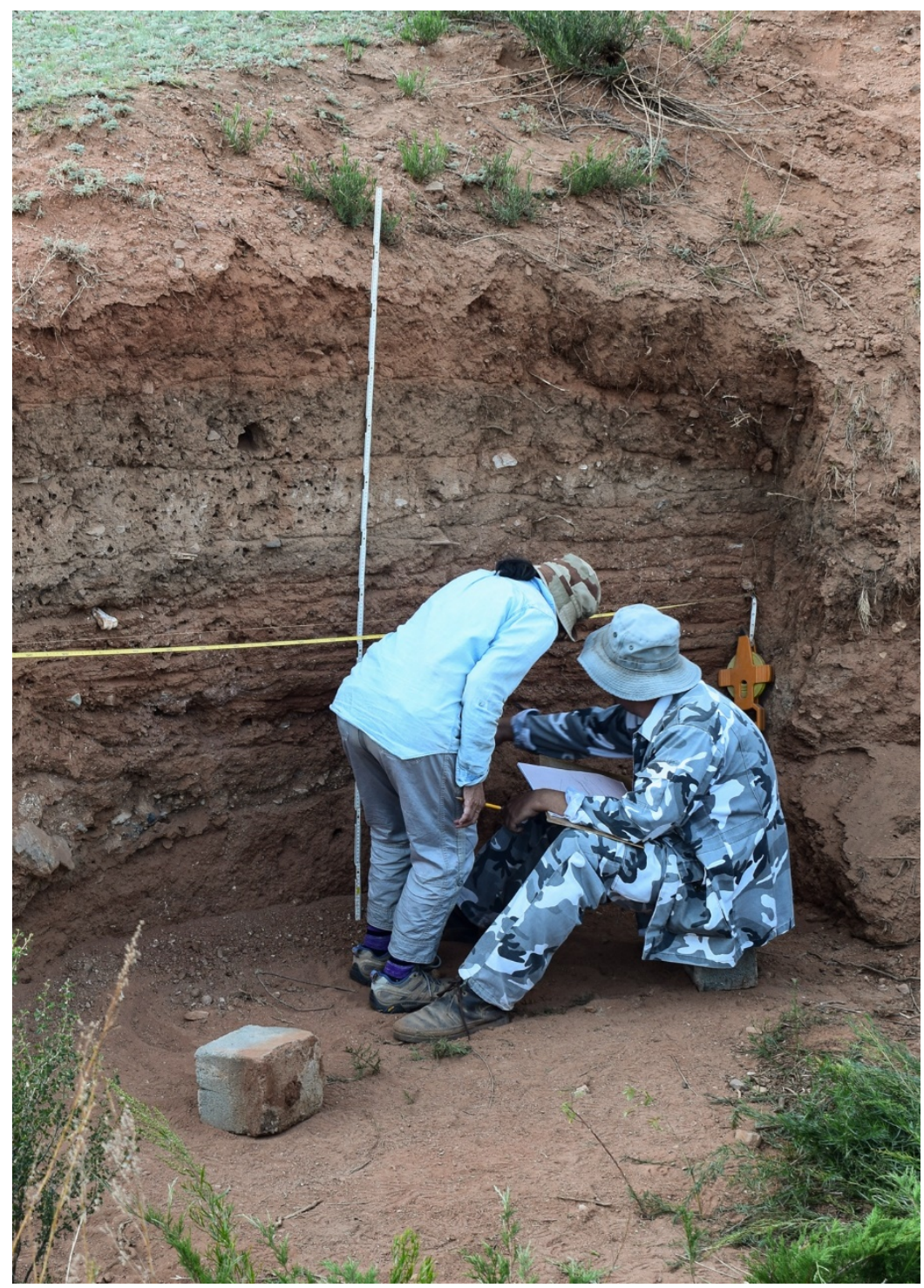

Figure 5. Profile of the Iron Age Site at Upper Juuku, two archaeologists working at profile. 
3.5.1 Settlement 2 situated at an upper terrace at an elevation of $2090 \mathrm{~m}$ asl. It is a series of double walled stone alignments of at least four large room blocks and measures about $17.5 \mathrm{~m} \mathrm{X} 12 \mathrm{~m}$. The stratigraphic profile examined is a west-facing cut found at a deep erosional gully that dissects this upper terrace (Figure 6). When this cut was first discovered, s sheep scapula was found at about $1.3 \mathrm{~m}$ in depth from the present ground surface. The cultural levels at this profile of complex since the house fill represents at least three or four different occupation levels. At about 1.7 to $2.0 \mathrm{~m}$ below the surface are a series of thin buff-colored plastered floors or laminations that may represent the different layers of an ancient sufa (sleeping bench). Burnt wood (charcoal) sample and two flotation samples were taken at approximately 50 to $80 \mathrm{~cm}$ below the present ground sutface. The site is dated to the Medieval Qarakhanid period and has an approximate radiometric dating of $990-1050$ cal AD (see Table 4). This is also confirmed by the Medieval redware ceramics and a granite grinding stone found on the surface of this settlement. The archaeobotanical remains showed a paucity of seeds from the 11.5 liters of collected sample, only one barley seed was identified, the rest were wild seeds [31].

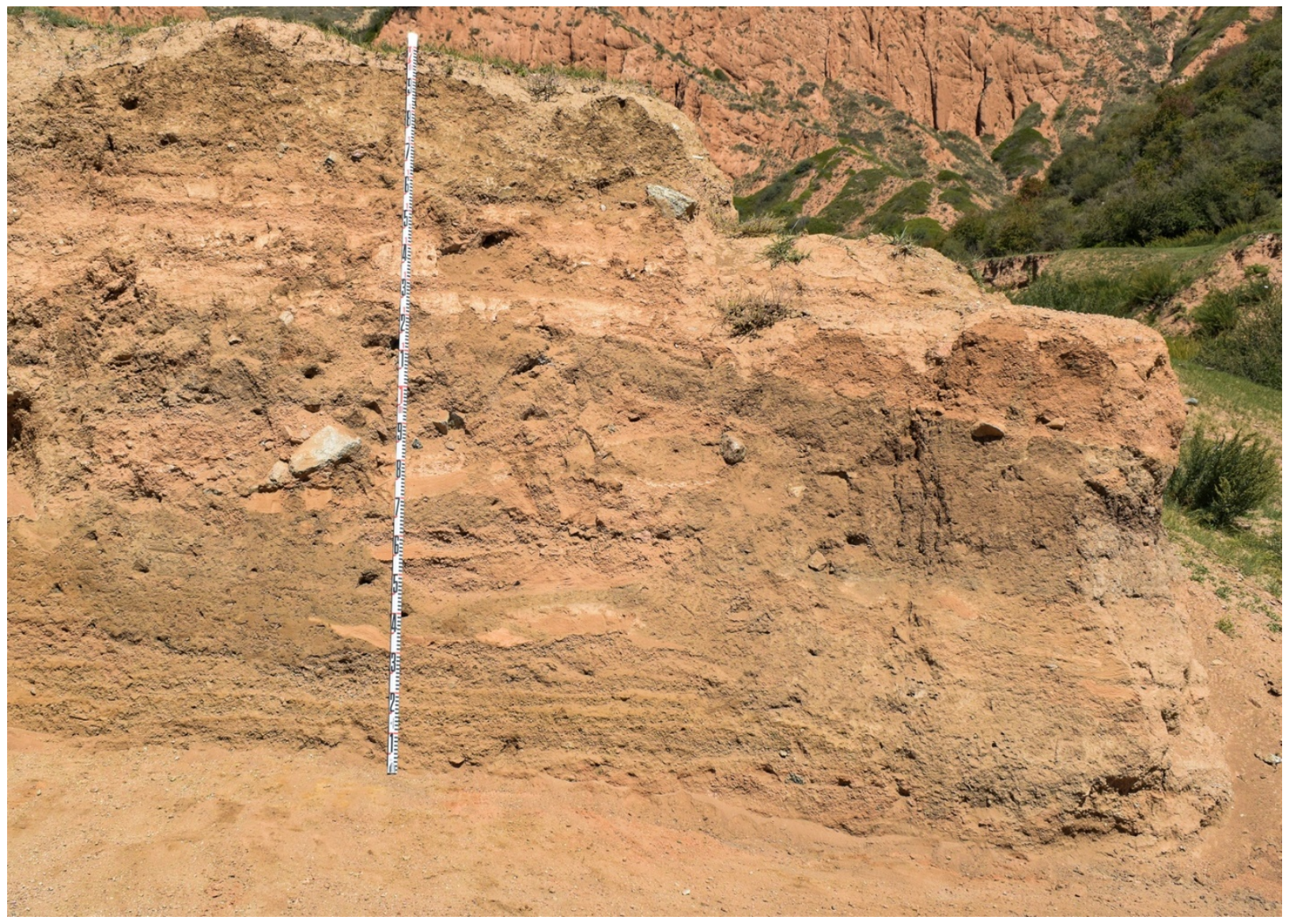

Figure 6. Photograph at Profile of Medieval Settlement at Upper Juuku.

\subsubsection{Radiometric Dating:}

At Settlement 1 (Iron Age site) and Settlement 2 (Qarakhanid Phase, Medieval Period charcoal samples were taken from the profiles. AMS dating was obtained from both settlements. The following dates are reported in Table 5. 
Table 5. Radiometric dates from the Upper Juuku Valley, Settlement 1 and Settlement 2.

\begin{tabular}{cccc}
\hline Site No. & Laboratory No. & Calibrated Dates BC/AD & \multicolumn{2}{c}{$\begin{array}{c}\text { Conventional radiocarbon age } \\
\text { (BP) }\end{array}$} \\
\hline Settlement 1 (\#183) & Beta-603779 & $(94.5 \%) \quad 22-206 \mathrm{cal} \mathrm{AD}$ & $1928-1744 \mathrm{cal} \mathrm{BP}$ \\
\hline Settlement 2 (\#165) & Beta-603781 & $(81.7 \%) 978-1130 \mathrm{cal} \mathrm{AD}$ & $972-902 \mathrm{cal} \mathrm{BP}$ \\
\hline & & $(11.4 \%) 1082-1130 \mathrm{cal} \mathrm{AD}$ & $868-820 \mathrm{cal} \mathrm{BP}$ \\
\hline & “ & $(2.3 \%) 1127-1151 \mathrm{cal} \mathrm{AD}$ & $813-799 \mathrm{cal} \mathrm{BP}$ \\
\hline
\end{tabular}

These results were obtained using AMS radiocarbon methods and have been calibrated using INTCAL20 by Beta Analytic, Inc [39]. They are the exact results from the Beta Analytic Laboratory report.

\subsection{Mortuary Complexes}

There were many lines of Iron Age burial mounds found in both Upper and Lower Juuku. The largest numbers of burial sites, were earthen or stone mounds known as kurgans. In Figure 7 there are two large Saka period earthen mounds found in the Lower Juuku. These earthen kurgans are identified as Saka period elite kurgans based on their size, earthen construction, and the krepida (rock apron) found on the north side of the kurgan [41].

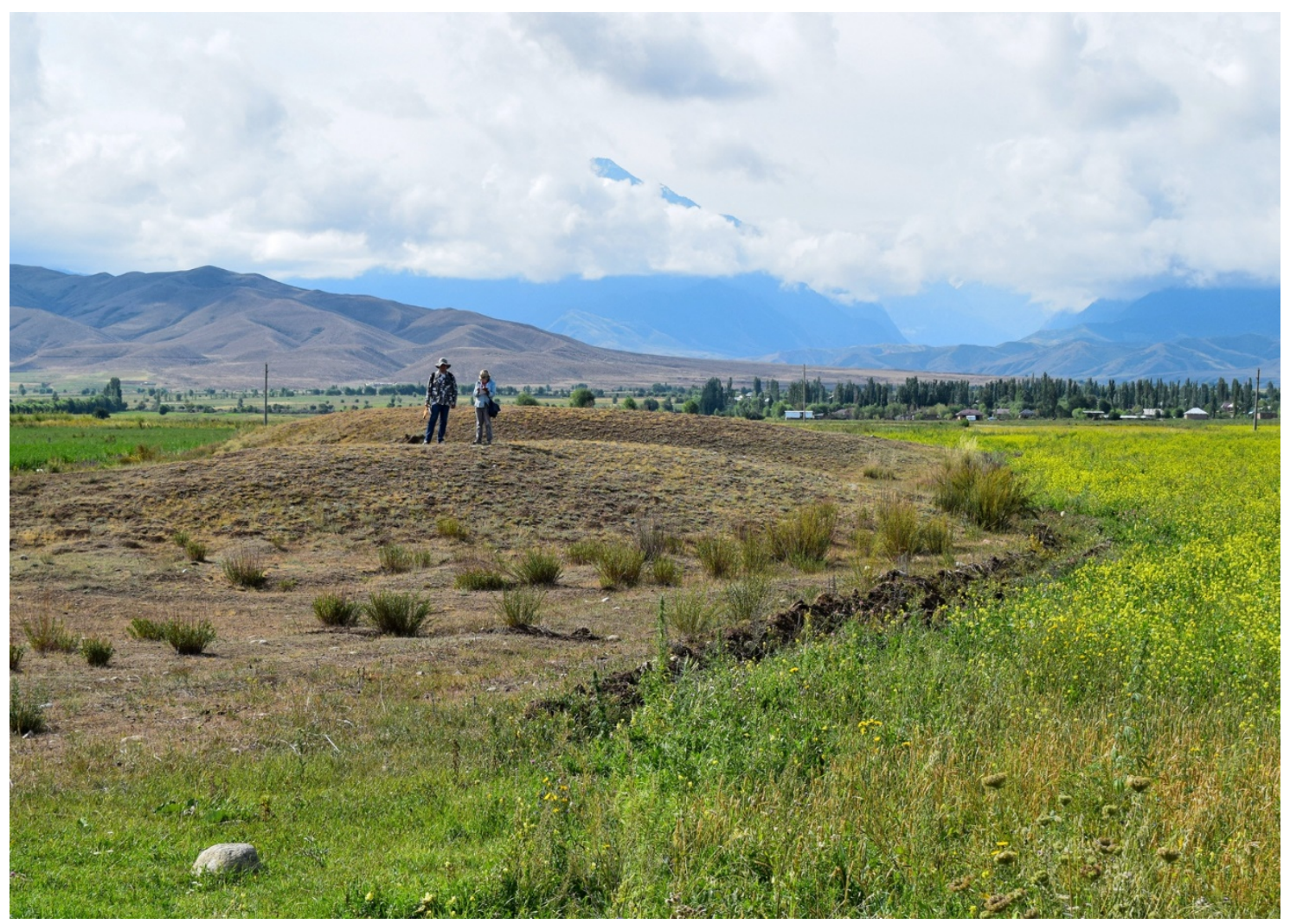

Figure 7. Photograph of large earthen Saka kurgans found in the Lower Juuku Valley.

\subsubsection{Stone corral}

In the Upper Juuku Valley a stone corral was located. Currently the chronological period for this stone corral is unknown. This corral is an important feature of agropastoralism in the Upper Juuku Valley (Figure 8). 


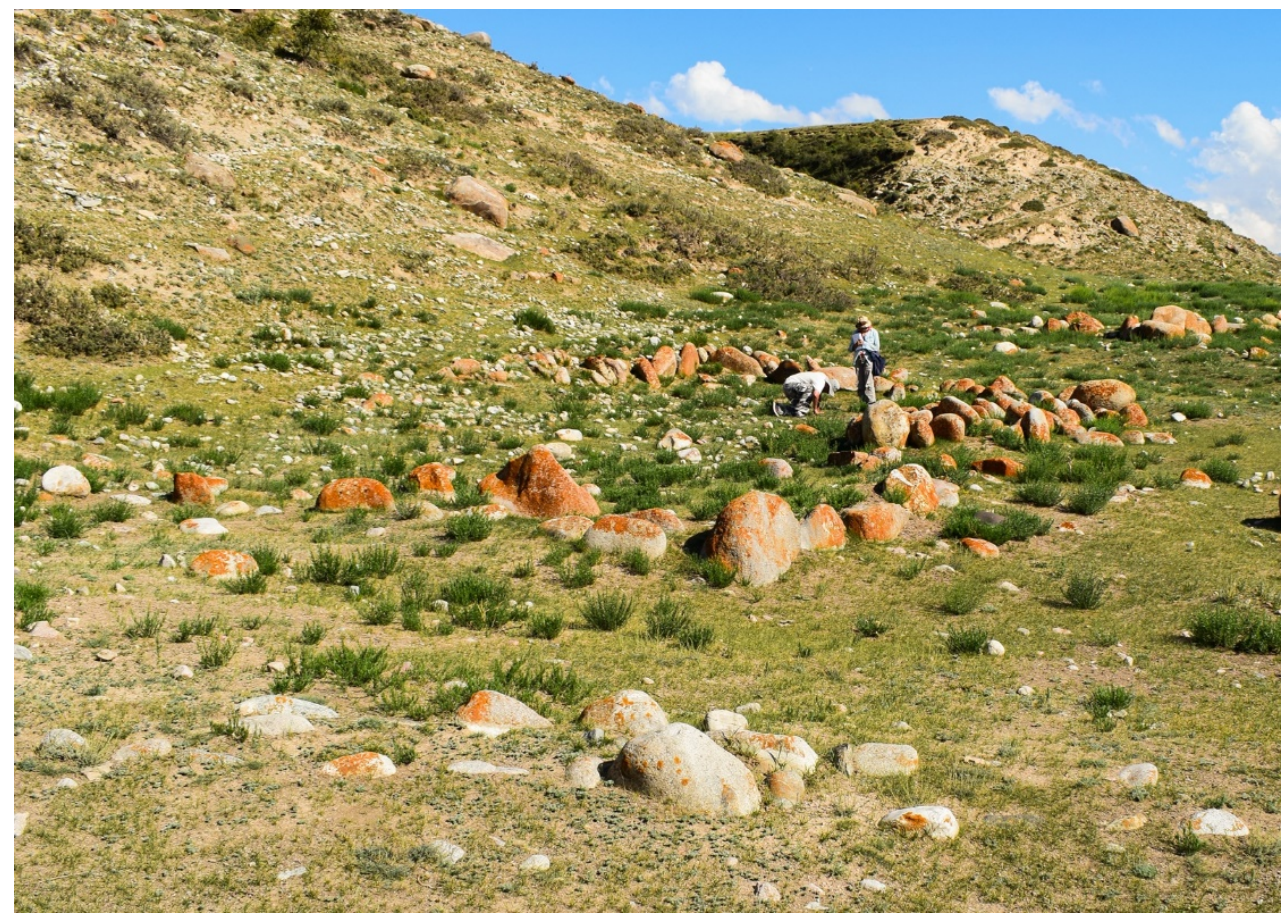

Figure 8. Photograph showing a stone corral in Upper Juuku.

\subsubsection{Artifacts}

Many artifacts were either found as isolated finds or as parts of scatters. In Figure 9 is a granite grinding stone found as an isolated surface find. In Figure 10 shows the interior of redware ceramic sherds, some with fabric impressions and red slip. These ceramic pieces probably date to the Iron Age and represent hand-made or slow wheel ceramics. A detailed description of fabric impressed ceramics and actual fabric fragments from Bronze and Iron Age contexts at the site of Begash in the Dzhungari Alatau Mountains of southeastern Kazakhstan by Paula Doumani Dupuy and her colleagues [42]. Similar redware sherds, sometimes with light slip have been found at Iron Age sites in the Talgar region of southeastern Kazakhstan [14,43].

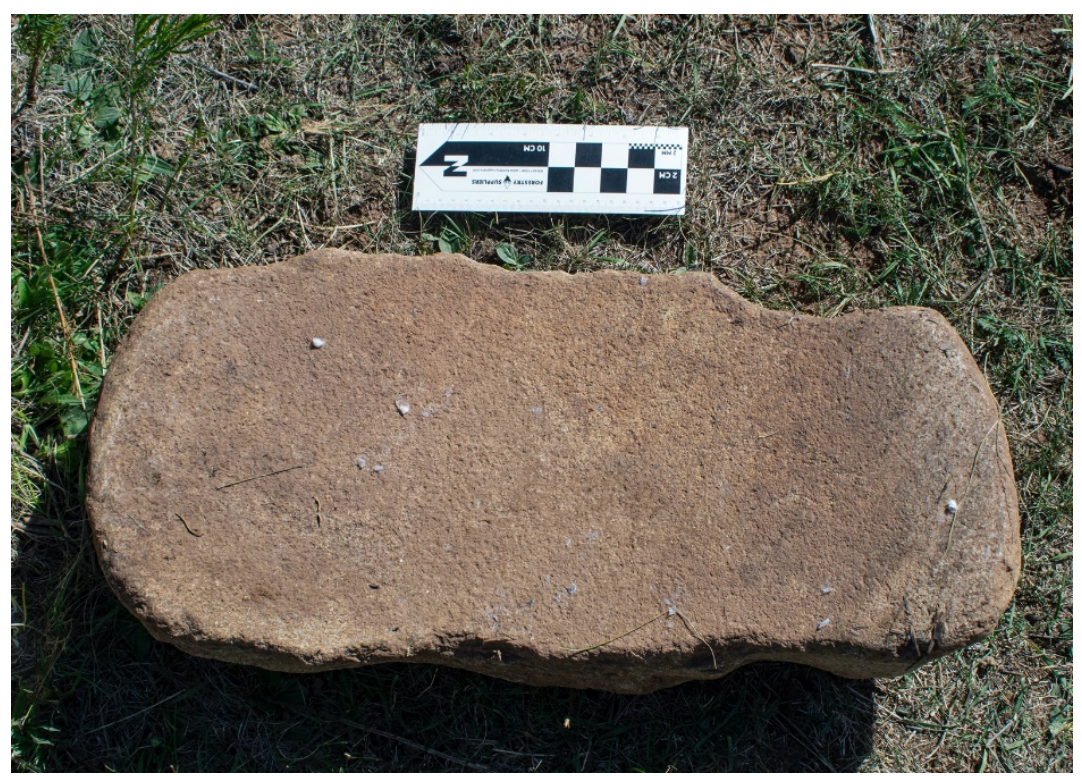

Figure 9. A granite grinding stone found on the surface. 


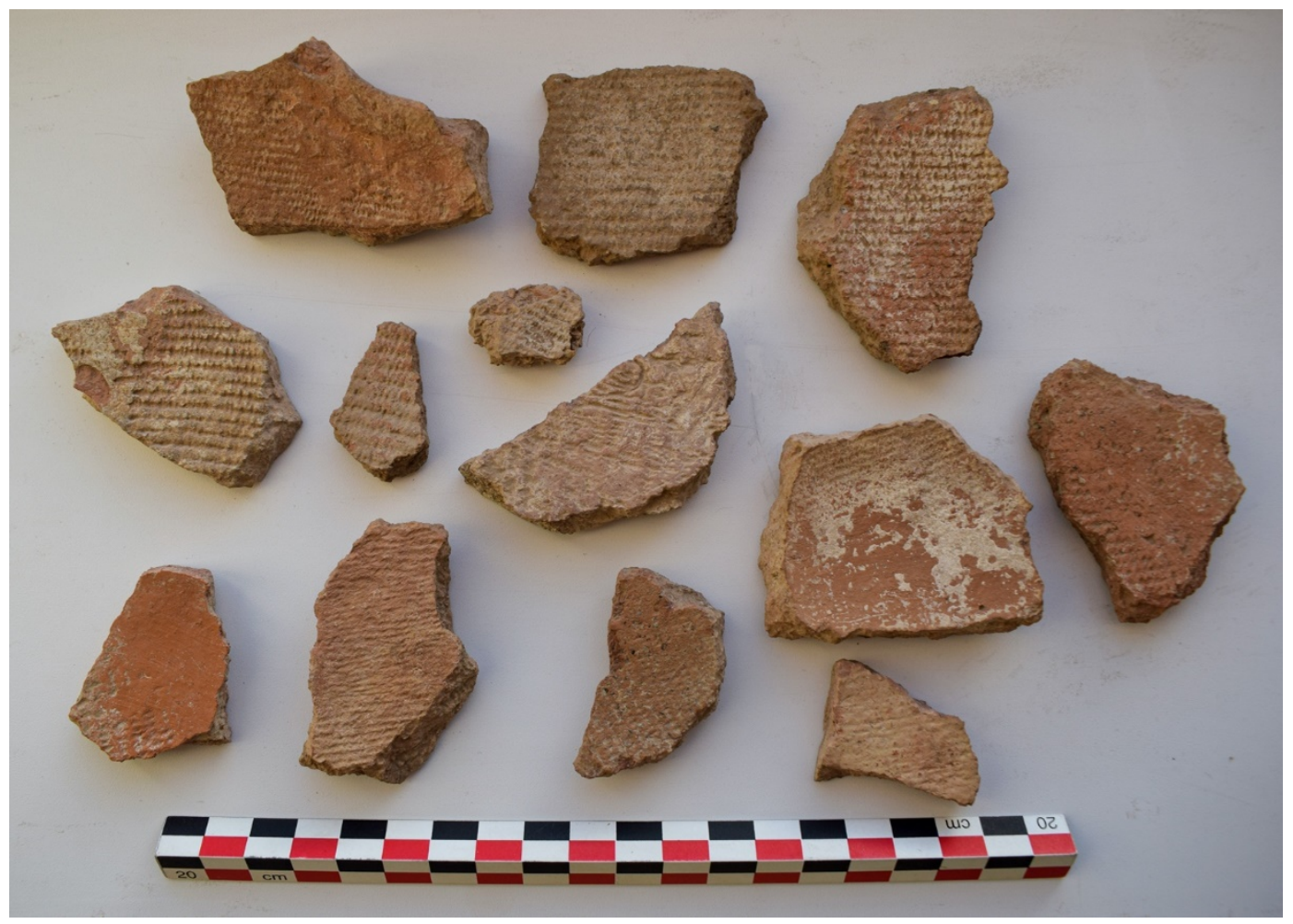

Figure 10. Redware ceramic sherds, interiors showing fabric impressions and red slip, probably Iron Age period ceramics.

\section{Discussion}

Pedestrian surveys in the innermontane regions of Central Asia remain a continued practice for field archaeology, especially for examining ancient landscapes and land use patterns. While new methodologies such as the use of UAVs enhance the accuracy of archaeological survey methods, pedestrian surveys allow archaeologists to groundtruth archaeological features visible from satellite or drone imagery. Moreover archaeological survey is immensely satisfying for the field archaeologist as a heuristic tool for understanding ancient settlement and subsistence patterns. The field archaeologist experiences the actual spatial and landscape features of material cultural remains discovered on terraces, ridges, valleys, and along river or stream beds. This experiential aspect of fieldwork creates a memorybank for recording and understanding settlements and activity areas on physical landscapes. One good example of this, is when our team has discovered artifacts in ploughed and harvested fields. These discoveries are "windows" into the sub-surface features of pits, houses, and artifact scatters. The results from the intensive survey at these two polygons within a single valley now provide further impetus for more complete survey coverage of this valley and for future excavation projects.

The site density at these two polygons in the Juuku Valley appears to be much higher than site densities on the Talgar alluvial fan on the edge of the northern Tian Shan mountains. Moreover, the Juuku Valley appears to have a larger representation of sites from the Bronze Age through historic periods. Thus the Juuku Valley is an excellent microregion for more in-depth investigations of agro-pastoral systems over a long period of time and in different cultural phases. In 2021 we did further reconnaissance of Iron Age settlements, often noting that it was more difficult to find and locate early period settlements from the Bronze and Iron Ages than we initially expected. Most likely earlier Bronze and Iron Age settlements have been buried by more recent Medieval and historic sites or have been destroyed by modern agricultural practices such as ploughing and irrigation. In the Lower Juuku, where the majority of large-scale tractor and irrigation 
agriculture occurs, surveys may yield better results if conducted in the early spring or early fall before intensive cropping and after harvesting.

Today the Lower Juuku Valley is well-suited for the cultivation of wheat, barley, oats and fodder crops during the summer months when large tracts of land can be irrigated and cultivated using large machinery. Sheep, goats, cattle and horses are often pastured on the agricultural stubble after harvest. The Upper Juuku is more suitable for summer pasturelands for cattle, sheep, goats, and horses. Its rich forest and riparian areas attract a variety of wild animals and fish, deeming this area desirable for upland herding, fishing, and foraging. In the past there may have been pockets of arable land in the Upper Juuku for the cultivation of short-season crops such as barley and millets.

\section{Conclusions}

Archaeological surveys are necessary in this region of north-central Kyrgyzstan for two main reasons: (1) the upland areas far from the perimeter of Lake Issyk kul are poorly known by Kirghiz archaeologists; and (2) the south side of Lake Issyk kul is an under-developed tourst area. As this area continues to develop as a tourist area and as an agricultural region for the cultivation of wheat, barley, and fodder, more archaeological sites will be destroyed. Settlement archaeology, especially for the prehistoric periods, is little known in the Republic of Kyrgyzstan. Recently research on Epipaleolithic through Neolithic layers at Obishir have been conducted by international teams of archaeologists [44-46]. As archaeologists begin to explore the early beginnings of foraging, pastoral, and agricultural economies in Kyrgyzstan, surveys like the Juuku Valley and the Kochkor surveys will become more essential for the next generation of archaeologists $[20,21,47]$. Our work represents a modest first step in establishing systematic archaeological survey methods in order to reconstruct settlement-subsistence systems in this region of Central Asia. The results of the surveys will also be used to select areas for test excavations and large-scale block excavations of both mortuary and settlement complexes in order to examine early subsistence economies. Finally, it is our hope that these physical, archaeological, and cultural landscapes will be preserved through local and national efforts [48]. An inventory of archaeological loci then becomes the initial path towards preserving such fragile landscapes.

Author Contributions: C.Chang and P.A. Tourtellotte provided the conceptualization of the paper. The methodolology for the field surveys was designed by S.S. Ivanov and P.A.Tourtellotte; quantitative analyses and tables was prepared by C.Chang; validation of results were undertaken by S.S.Ivanov, C.Chang and P.A.Tourtellotte; resources were obtained by all three authors; writing, including review \& editing was performed by all three authors; visualization including photography and digital mapping, and the graphical abstract was designed by P.A.Tourtellotte; field and laboratory supervision undertaken by S.S.Ivanov; project administration conducted by S.S. Ivanov; funding acquisition by C.Chang.

Funding: The funding for this fieldwork study was supplied by the National Geographic Society, "The effects of earthquakes on Inner Tian Shan passages: Iron Age and Medieval Landscapes" (NGS-59769R-19). No funds were provided for publication.

Data Availability Statement: The results of the archaeological surveys are currently archived by C.Chang (USA) and S.S.Ivanov (Kyrgyz National University). These include GPS data points, digital mapping, fieldnotes, and preliminary reports. The radiometric data is archived by Beta Analytic Laboratory in Coral Gables, Fl (USA). Artifact collections (ceramics, metal, stone) are archived at the Kyrgyz National University in the Faculty of Far Eastern Studies. The archaeobotanical material is archived at the Max Planck Institute of Human History, Archaeology Department under the supervision of Robert N. Spengler, III, Laboratory Director of the Archaeobotany Laboratory. 
Acknowledgments: The authors of this paper are also grateful to the fieldwork support provided in 2019 by Kathryn J. Franklin, Department of Classical and Medieval Studies at the University of London (Birbeck College). The preliminary archaeobotanical studies were generously conducted by Basira Mir-Makmadad and Robert N. Spengler, III at the Max Planck Institute for the Study of Human History, Archaeology Department in 2021. Beta Analytic, Inc. (Coral Gables, Florida) conducted the AMS radiometric dating of three charcoal samples.

Conflicts of Interest: The funders had no role in the design of the study; in the collection, analyses, or interpretation of data; in the writing of the manuscript, or in the decision to publish the results

\section{References}

1. Frachetti, M.D. Multiregional emergence of mobile pastoralism and nonuniform institutional complexity across Eurasia. Current Anthropology,2012, 53(1), 2-38.

2. Spengler, R.III. Fruit from the Sand: the Silk Route origins of the foods we eat; University of California Press: Berkeley, USA, 2019.

3. Fuller, D.Q.; Lucas L. Adapting crops, landscapes, and food choices: Patterns in the dispersal of domesticated plants across Eurasia. In Human Dispersal and Species Movement; Eds.: Boivin, N., Petraglia, M., Cressard, R.: Cambridge University Press: Cambridge, UK, 2017, pp. 304-331.

4. Hermes, T.; Frachetti, M.D.; Doumani Dupuy, P.; Mar'yashev, A.;Nebel, A.; Makarewicz, C.A. Early integration of pastoralism and millet cultivation in Bronze Age Eurasia. Proc. R. Soc. B.: Biological Sciences 2019, Volume 286: 20191273. DOI 10.1098/rspb.2019.1273

5. Motuzaite-Matuzeviciute, G. The earliest appearance of domesticated plant species and their origins on the western fringes of the Eurasian Steppe. Documenta Praehistorica 2012, Volume 39; pp. 1-21. DOI 10.4312/dp.39.1

6. Lister, D.L; Jones, H.; Oliveira, H.R.; Petrie, C.A.; Liu, X; et al. Barley heads east: Genetic analyses reveal routes of spread through diverse Eurasian landscapes. PLoS ONE, 2018, Volume 13(1): pp. e0196652. DOI 10.1371/journal.pone.0196652

7. Scorrano, G.; Yediay, F.E.; Pinotti,T.; Feizabadifarahani, M.; Kristiansen, K. The genetic and cultural impact of the Steppe migration into Europe. Annals of Human Biology, 2021, Volume 48(3); pp. 223-233. DOI 10.1080/03014460.2021.1942984

8. Jeong, C.; Balanovsky, 0.; Lukaniova, E.; Kahbatkyzy,N.; Flegontov, P.; et al. The genetic history of admixture across inner Eurasia. Nat Ecol Evol, 2019, Volume 3(6): pp.944-976. DOI 10.1038/s41559-019-0878-2

9. Gokcumen, O.; Frachetti, M.; The Impact of Ancient Genome Studies in Archaeology. Annual Review of Anthropology, 2020, Volume 41(1): pp. 277-298. DOI 10.1146/annurev-anthro-010220-074353

10. Ventresca Miller, A.R.; Makarewicz, C.A.). Isotopic approaches to pastoralism in prehistory: Diet, mobility, and isotopic reference sets. In Isotopic Investigations of Pastoralism in Prehistory, Eds.; Ventresca Miller, A.R.; Makarewicz, C.A. Taylor and Frances: London, UK: 2017: pp. 1-14.

11. Ventresca Miller, A.R.; Haruda, A.; Varfolomeev, V.; Goryachev, A.; Makarewicz, C.A. Close management of sheep in ancient Central Asia: evidence for foddering, transhumance, and extended lambing seasons during the Bronze and Iron Ages. STAR: Science \& Technology of Archaeological Research, 2020, Volume 6(1): pp. 41-60.

12. Chang,C.; Tourtellotte, P.A.; The Kazakh-American Talgar Project Archaeological Field Surveys in the Talgar and Turgen-Asi Areas of Southeastern Kazakhstan: 1997-1999 by Claudia Chang and Perry A. Tourtellotte. In Kurgans, Ritual Sites, and Settlements Eurasian Bronze and Iron Age Eds. Davis-Kimball, J.; Murphy, E.M.; Koryakova, L.; Yablonsky, L.T. British Archaeological Reports, 2000, International Series 890, pp. 83-88.

13. Chang, C.: Tourtellotte, P.; Baipakov, K.M.; Grigoriev, F.P. The Evolution of Steppe Communities from the Bronze Age to Medieval Periods in Southern Kazakhstan (Zhetysu). Almaty, KZ; Sweet Briar, VA, USA; 2002.

14. Chang, C. Rethinking prehistoric Central Asia: shepherds, farmers, and nomads. Routledge: Abingdon, UK. 2017. 
15. Ullah, I.I.T; Chang, C.; Tourtellotte, P. Water, dust, and agro-pastoralism: Modeling socio-ecological co-evolution of landscapes, farming, and human society in southeast Kazakhstan during the mid to late Holocene. Journal of Anthropological Archaeology, 2019,Volume 48, pp. 101067. DOI 10.1016/j.jaa.2019.101067

16. Frachetti, M.D. Pastoralist landscapes and social interaction in Bronze Age Eurasia. University of California Press: Berkeley, CA.,USA, 2009.

17. Beardmore, R.; Bonora, G.L.; Kurmankulov, Z. (2008). Preliminary Report on the 2007-2008 IAEK Campaigns in the Syrdarya Delta. East and west 2008, Volume 58(1-4), pp.385-390.

18. Caspari, G.; Betts, A.; Jia, P. The Bronze Age in the Western Tianshan, China: A new model for determining seasonal use of sites. Journal of Archaeological Science: Reports 2017, Volume 14: pp. 12-20. DOI 10.1016/j.jasrep.2017.05.036

19. Tian, D.; Festa, M.; Cong, D.; Zhao, Z.; Jia, P.W.; Betts, A. New evidence for supplementary crop production, foddering and fuel use by Bronze Age transhumant pastoralists in the Tianshan Mountains. Scientific reports, 2021, Volume 11(1), pp. 1-13.

20. Rouse, L.M.; Krumnow, J. On the fly: Strategies for UAV-based archaeological survey in mountainous areas of Central Asia and their implications for landscape research. Journal of Archaeological Science Reports 2020,30: 102275. https/doi.org/10.1061/jasrep.2020.102275

21. Rouse, L.M.; Tabaldiev, K; Motuzaite Matuzeviciute,G. Exploring Landscape Archaeology and UAV-Based Survey in the Kochkor Valley, Kyrgyzstan. Journal of Field Archaeology, 2021, Volume 47(1): 32-58. DOI: 10.1080/00934690.2021.1945744

22. Matuzeviciute, G. M.; Mir-Makhamad, B.; Tabaldiev, K. The first comprehensive archaeobotanical analysis of prehistoric agriculture in Kyrgyzstan. Vegetation History and Archaeobotany, 2021, Volume 30(6):743-758.

DOI: $10.1007 / \mathrm{s} 00334-021-00827-0$

23. Motuzaite Matuzeviciute, G.; Tabaldiev, K.; Hermes, T.; Ananyevskaya, E.; Grikpedis, M.; Luneau, E.; ... Rouse, L. M. Highaltitude agro-pastoralism in the Kyrgyz Tien Shan: New excavations of the Chap farmstead (1065-825 cal BC). Journal of Field Archaeology, 2020, 45(1), 29-45. DOI:10.1080/00934690.2019.1672128

24. Motuzaite Matuzeviciute, G.; Hermes, T. R.; Mir-Makhamad, B.; Tabaldiev, K. Southwest Asian cereal crops facilitated high-elevation agriculture in the central Tien Shan during the mid-third millennium BCE. PloS ONE, 2020, 15(5), e0229372. DOI: 10.1371/journal.pone.0229372

25. Spengler III, R. N.; Miller, A. V.; Schmaus, T.; Matuzevičiūtė, G. M; Miller; B. K., Wilkin,S.; ... Boivin, N. An Imagined Past? Nomadic Narratives in Central Asian Archaeology. Current Anthropology, 2021, 62(3), 251- 286.

https://www.journals.uchicago.edu/doi/10.1086/714245

26. Giralt, S.; Julia, R.; Klerkx, I.; Riera, S.; Leroy, S.: et al. 1,000-Year Environmental History of Lake Issyk-Kul. In Dying and Dead Seas Climatic Versus Anthropic Causes, Eds. Nihoul, J.C.J.; Zavialov, P.O.; Micklin, P.P.; Springer, Netherlands: Dordrecht, Netherlands, 2004, Volume 36, pp. 253-285. Series Title: NATO Science Series: IV: Earth and Environmental Sciences. DOI: 10.1007/978-94-007-0967-6_10

27. Korjenkov, A.M. (Editor). 2018. Sil'nye Istoricheskie I Paloesimletryaseniya Priissi'kuly'ya I ih Polozhenenyie v Strukture Severnogo Tyan'shanya (Strong Earthquakes, Historical and Ancient Earthquakes of Issyk kul and Their Position in the Formation of the Northern Tian Shan Range). IFZ: Moscow, Russia, 2018, pp.1-173.

28. Strelnikov, A.A; Korzhenkov, A.M. (2021). Destruction of medieval archaeological monuments by strong earthquakes in the Southwestern Issyk-Kul Basin, Tien Shan. Seismic Instruments, 2021, Volume 57(1), pp. 55-74.

29. Cappers, R.T.; Bekker, R.M. A manual for the identification of plant seeds and fruits, 2022, Volume 23. Barkhuis: The Netherlands.

30. Neef, R., Cappers, R.T., \& Bekker, R.M. Digital atlas of economic plants in archaeology,2012, Volume 17. Barkhuis: The Netherlands. 
31. Mir-Makhamad,B.(Ph.D. candidate, Max Planck Institute for the Science of Human History, Department of Archaeology, Jena, Germany); Spengler III, R.N.(Laboratory Director, Archaeobotanical Laboratory, Max Planck Institute for the Science of Human History, Department of Archaeology, Jena, Germany). Preliminary Archaeobotanical Report on the Juuku Valley, 2021. (Unpublished work).

32. Dunnell, R.C.; Dancey, W.S. The siteless survey: a regional scale data collection strategy. In Advances in archaeological method and theory, Editor M.B.Schiffer, 1983; Academic Press: New York, USA; Volume 6, pp. 267-287.

33. Cherry, J.F.; Davis, J.L.; Mantzourani, E. (1991). Landscape history and archaeology. In Northern Keos in the Cycladic Islands, Eds. Cherry, J.F.; Davis, J.L.; Mantzourani,E. Institute of Archaeology, University of California: Los Angeles,CA., USA, 1991; pp. 57-68.

34. Akishev, K.A.; Kozhomberdiev,I. Arkheologisheskiye Pamyatniki Priiskk'ukul'ya. (Archaeological Monuments in the vicinity of Issyk Kul), Izdatel'sko <<Ilim>>:USSR, 1975.

35. Ivanov, S.S. K проблеме культурного разрыва на рубеже сакского и усуньского периодов в Притяньшанье (Оn the problem of the cultural gap at the turn of the Saka and Wusun periods in the area surrounding the Tian Shan mountains). Stratum plus. Aрхеология и культурная антропология, 2016, Volume 3: 67-86.

36. Biran, M. The Qarakhanids' Eastern Exchange: Preliminary Notes on the Silk Roads in the Eleventh and Twelfth Centuries. In Proceedings of the Conference: Complexity of Interaction along the Eurasian Steppe Zone in the First Millennium CE, Bonn, Germany, Eds. Bemman, J.; Schamuder, M; Vor-und Frubgeschitchtliche Archaologie Rheinische FriedvichWilhelms-Universitat Bonn,2015, Bonn Contributions to Asian Archaeology, Volume 7: 575-595.

37. Vinnik, D.F.K. K istoricheskoi topographii srednevekov'ih Iss'ik kulskoi kotovin'ye/ Drevnyaya i srednevekovaya kul'tura Kirgizstana (The historical topography of medieval Issyk kul basin /Ancient Medieval Cultures of Kyrgyzstan), 1967, USSR, Republic of Kirghizstan, Frunze.

38. Amanbaeva, B.E.; Kol'chenkov,B.A.; Sulaimanova, A.T. Archelogicheskiye Pamyatniki na Kirgi'zstanskom uchastke Velikogo Shelkovogo Puti (Archaeological Monuments of the Kyrgyzstan portion of the Great Silk Road). Institut istorii i kul'tornogo NAN KR (Institute of History and Culture: Bishkek,Republic of Kyrgyzstan, 2015.

39. Reimer, P.T.; Austin, W.E.N.; Bard,E.; Bayliss, A.; Blackwell, P.G.....The IntCal20 Northern Hemisphere Radiocarbon Age Calibration Curve (0-55 cal kBP). Radiocarbon, 2020 Volume 62(4): 725-757.

40. Mir-Makhamad, B.; Mirzaakhmedov, S.; Rahmonov, H.; Stark, S.; Omel'chenko, A.; Spengler, R.N. Qarakhanids on the Edge of the Bukhara Oasis: Archaeobotany of Medieval Paykend. Econ Bot. 2021, online. DOI 10.1007/s12231-021-09531-6

41. Parzinger, H. Burial mounds of Scythian elites in the Eurasian steppe: New discoveries. Journal of the British Academy, 2017, Volume 5:pp. 331-35. DOI 10.5871/jba/005.331

42. Doumani Dupuy, P.N.; Spengler, R.N.; Frachetti, M.D. Eurasian textiles: Case studies in exchange during the incipient and later Silk Road periods. Quaternary International, 2018, Volume 468: pp. 228-239. DOI 10.1016/j.quaint.2016.09.067

43. Heinsch, M.; Vandiver, P.B.; Lyublyanovics, K.; Choyke, A.M.; Reedy, C.;Tourtellotte, P.; Chang, C. Ceramics at the emergence of the Silk Road: a case from southeastern Kazakhstan. MRS Online Proceedings Library (OPL), 2015, 1656. Mater. Res. Soc. Symp. Proc. Vol. 15 (C) 2015 Materials Research Society DOI:10.1557/opl.2015.841

44. Shnaider, S.V.; Krajcarz, M. T.; Viola, T. B.; Abdykanova, A.; Kolobova, K. A.; Fedorchenko, A. Y.; ... Krivoshapkin, A. I. New investigations of the Epipalaeolithic in western Central Asia: Obishir-5. Antiquity, 2017, Volume 91:e3. DOI: 10.15184/aqy.2017.213

45. Osipova, E.; Danukalova, G.; Brancaleoni, G.; Krajcarz,M. T.; Abdykanova, A.; Shnaider, S.. Palaeoenvironmental conditions of the Palaeolithic-Neolithic transition in the Fergana Valley (Central Asia)-New data inferred from fossil molluscs in Obishir-V rockshelter (Kyrgyzstan). Quaternary International, 2021,Volume 605: 287-299. 
46. Taylor, W.T.; Pruvost, M.; Posth, C.; Rendu, W.; Krajcarz, M. T.; Abdykanova, A.; ... Shnaider, S. (2021). Evidence for early dispersal of domestic sheep into Central Asia. Nature Human Behaviour, 2021, Volume 5(9): 1169-1179.

47. Tabaldiev, K.Sh. (2011). Dreoniye pamyatniki Tyan Shanya (Ancient monuments of the Tian Shan). 2011, Bishkek, 318 pages.

48. Chang, C. Archaeological sites, cultural heritage, and sustainable development in the Republic of Kazakhstan. In Education, Human Rights and Peace in Sustainable Development; Volume 87: Eds. Nugmanova,M.; Mikkola, H.; Rozanov, A.; Komleva, V.Intechopen: London, UK, 2019,Volume 87, pp. 1-8. DOI: 10.5772/intechopen.86916 